\title{
'Aanhalings' van die Ou Testament deur die Nuwe Testament: Hosea 11:1/Matteus 2:15
}

\author{
WS Prinsloo
}

\begin{abstract}
Quotations of the Old Testament in the New Testament: Hosea 11:1/Matthew 2:15

The quotation of Hosea 11:1 in Matthew 2:15 does not cancel the original meaning of Hosea 11:1. Neither can Matthew 2 be implemented as a criterium to interpret Hosea 11. Both Hosea 11 and Matthew 2 have their own unique message and both have to be taken equally seriously into consideration.
\end{abstract}

\section{INLEIDEND}

Die verhouding tussen die $\mathrm{Ou}$ en die Nuwe Testament het vanaf die vroeë geskiedenis van die Kerk 'n groot en feitlik onoplosbare probleem geskep. Die basiese probleem bestaan daaruit dat die Ou Testament, 'n pre-Christelike boek en die produk van die Judees-Israelitiese gemeenskap, deel vorm van die Christelike kanon. Hoe moet 'n preChristelike boek in die tyd ná Christus gebruik word?

By die bespreking van dié gekompliseerde probleem pas dit ' $n$ mens om nederig te bly en nie te maak asof daar net een oplossing is en om alle ander pogings om die probleem te probeer oplos, te verketter nie.

Ons moet dus enersyds daarteen waak om op simplistiese wyse kitsklaar antwoorde gereed te hê. Andersyds mag ons nie die probleem ignoreer asof dit nie bestaan nie. Net so mag ons nie toelaat dat die $\mathrm{Ou}$ Testament of dele daarvan afgeskeep of geïgnoreer word omdat dit problematies is nie.

Om 'n oorsig van die saak te kry, sal ons moet kyk na verskillende modelle wat in die loop van die tyd aangewend is om hierdie probleem te probeer oplos.

Aangesien dit onmoontlik is om die hele probleem ten opsigte van die verhouding Ou Testament/Nuwe Testament te behandel, word hier slegs op een aspek gekonsentreer, naamlik die sogenaamde aanhalings

* Rede gelewer by die teologiese dag van die Fakulteit Teologie (Ned Geref Kerk), Universiteit van Pretoria op 11 Februarie 1986. 
van die Ou Testament deur die Nuwe Testament. Om dit nie in die lug te laat hang nie, word die saak geillustreer aan die hand van die twee tekste, naamlik Hosea 11:1 ('Toe Israel nog 'n kind was, het Ek hom al liefgehad, en Ek het hom, my seun, uit Egipte geroep') en Matteus 2:15 ('... So is vervul wat die Here deur 'n profeet gesê het: Uit Egipte het Ek my Seun geroep').

\section{POGINGS OM DIE VERHOUDING OU TESTAMENT/NUWE TESTAMENT TE BESKRYF}

'n Mens sou volledigheidshalwe talle skakerings van oplossingspogings kon noem (vgl Baker 1976: 97-397). Wat hier volg, maak egter nie aanspraak op volledigheid nie, maar gee op 'n vereenvoudigde manier slegs die basiese benaderingwyses weer:

\subsection{Die Ou Testament en die Nuwe Testament staan antiteties of kontrasterend teenoor mekaar}

Hierdie benaderingwyse oorbeklemtoon die feit dat die Ou Testament 'n pre-Christelike Boek is. Die Ou Testament word beskou as minderwaardig teenoor die Nuwe Testament. Dit word beskou as 'n wettiese of partikularistiese geskrif. Dit word soms tipeer as 'n geskiedenis van mislukking. Hierdie benadering vertoon 'n dualisme wat selfs so ver gegaan het om te sê dat die liefdevolle, genadige God van die Nuwe Testament ' $n$ ander God is as die wrede, toornige God van die $\mathrm{Ou}$ Testament. Hierdie benadering devalueer uit die aard van die saak die Ou Testament of dele daarvan. Die mees ekstreme vorm van dié benadering (bv Marcion) loop selfs daarop uit om die Ou Testament uit die kanon te wil haal.

\subsection{Oorbeklemtoning van die Ou Testament}

Hierdie model staan eintlik direk teenoor die voorafgaande en is geneig om die Ou Testament te beskou as dié deel van die kanon. Die Nuwe Testament word slegs beskou as 'n soort van verduidelikende addendum tot die Ou Testament. Hierdie benadering devalueer dus die Nuwe Testament. ' $n$ Mens sou selfs kon sê dat dit die betekenis van die koms en soendood van Jesus Christus ook relativeer. 


\subsection{Gedwonge Christosentriese benaderings}

Die algemene kenmerk van hierdie benaderings is dat Jesus Christus op gedwonge wyse in die Ou-Testamentiese teks ingelees word. Die probleem met dié benadering is dat daar nie genoeg rekening gehou word met die literêre, historiese en teologiese konteks van die teks van die Ou Testament nie. Die belofte/vervullingskema, tipologie en allegorie kan genoem word as voorbeelde van so 'n gedwonge Christosentriese benadering.

\subsection{Teosentriese benadering}

Ek persoonlik sou verkies om van 'n teosentriese benadering te praat. Dié uitgangspunt sluit nie die Christologiese benadering uit nie, maar wel in. Dit wil - afhangende van die betrokke teks - aandag gee aan al drie die Persone van die Drie-Eenheid.

Dit is belangrik om te beklemtoon dat daar 'n eenheid en kontinuiteit tussen die $\mathrm{Ou}$ en die Nuwe Testament is. Die eenheid bestaan veral daaruit dat beide Testamente van dieselfde God getuig. Die term Ou Testament beteken dat dit ' $n$ ouer Testament as die Nuwe Testament is, dit beteken egter nie dat dit verouderd is in die sin dat dit nie meer waarde het of dat dit minder gesagvol as die Nuwe Testament is nie.

Alhoewel daar ' $n$ eenheid is tussen die Ou Testament en die Nuwe Testament, is daar tog ook ' $n$ progressie, 'n beweging vanaf die $\mathrm{Ou}$ Testament na die Nuwe Testament toe. 'n Progressie in dié sin dat Jesus Christus se koms na die aarde toe die hoogtepunt is van God se heilshandeling met die mens. Wanneer ons as Christene (as mense uit die tyd ná die koms van Christus) uit die Ou Testament preek, sal ons nie anders kan as om rekening te hou met die koms, die kruisdood en die wederkoms van Jesus Christus nie. Dit beteken egter nie dat ons op meganiese of fundamentalistiese wyse vir Jesus Christus in elke OuTestamentiese teks sal inforseer nie. Alle legitieme eksegetiese hulpmiddels en metodes moet ingespan word ten einde te bepaal wat die boodskap en teologie van die betrokke Ou-Testamentiese teks is. Wanneer dit gedoen is, is dit die verdere taak van die prediker om in die lig van bogenoemde uitgangspunt die teks aktueel toe te pas vir die Christelike gemeente.

\section{HOSEA 11:1-11}

1. 'Toe Israel nog 'n kind was, het ek hom al liefgehad, en Ek het hom, my seun, uit Egipte geroep. 
2. Maar toe die Baäls hulle roep, het Israel my verlaat en vir die Baäls gaan offer, vir afgodsbeelde offers gebring.

3. Ek self het Efraim leer loop, Ek het hulle op my arms gedra, maar hulle wou nie erken dat dit Ek is wat vir hulle sorg nie.

4. Ek het hulle met sorg en liefde gelei, Ek was vir hulle soos iemand wat die juk oplig as dit sy trekdier skaaf. Ek het na Efraim toe afgebuk en hom gereeld kos gegee, 5 . want Ek wou nie hê dat hy weer na Egipte toe moet teruggaan nie of dat Assirië oor hom moet heers nie. Maar Efraim het geweier om hom te bekeer.

6. Daarom sal sy stede deur oorlog verwoes word en sy waarsêers uitgeroei word. Hulle sal deur die oorlog verteer word oor die raad wat hulle gegee het.

7. Omdat my volk my verlaat het, sal party van hulle opgehang word en die ander sal die slawejuk moet dra, 'n juk wat nie afgegooi sal word nie!

8. Maar hoe kan ek jou prysgee, Efraim? Hoe kan ek jou laat vaar, Israel? Hoe kan Ek jou vernietig soos Adma, met jou maak soos met Sebojim? Ek kan dit nie oor my hart kry nie. My liefde brand te sterk. 9. Ek sal my gloeiende toorn bedwing, Ek sal nie so ver gaan en Efraim uitwis nie, want Ek is God, nie 'n mens nie. Ek is die Heilige wat by jou is, Ek sal nie met woede ingryp nie.

10. Hulle sal die Here volg! Hy sal brul soos 'n leeu en wanneer Hy brul, sal sy kinders vol ontsag uit die weste kom.

11. Vol ontsag sal hulle soos voëls uit Egipte vlieg en soos duiwe uit Assirië. Ek sal hulle na hulle neste toe terugbring, sê die Here' (NAV, Kaapstad 1983).

Soos reeds aangetoon, word Hosea 11:1 in Matteus 2:15 'aangehaal'. Die vraag is: Is dit die bedoeling van Matteus 2:15 om 'n uitleg van Hosea 11:1 te gee? Hef die betekenis wat Matteus 2 aan Hosea 11:1 gee, die oorspronklike betekenis van Hosea 11:1 op? Beteken die 'vervul' in Matteus 2:15 dat Hosea 11:1 as belofte geinterpreteer moet word en dat dit eintlik oorbodig geword het nadat dit 'vervul' is?

Ten einde dié vrae - of dan ten minste sommige van hulle - te probeer beantwoord, sal daar na Hosea 11:1 binne sy literêre en historiese konteks gekyk moet word.

Hosea 11:1 maak deel uit van 'n kerugmatiese eenheid wat strek van Hosea 11:1 tot 11. 'n Resente en baie goeie kommentaar op Hosea bestempel Hosea 11:1-11 tereg as die afsluiting en ook die hoogtepunt 
van die tweede hoofdeel van die boek Hosea, naamlik hoofstukke 4-11 (Jeremias 1983: 139).

Ten opsigte van die literatuursoort van Hosea 11:1-11 kan gesê word dat dit op een enkele vers na (vgl vs 10 ) 'n orakel of godspraak is waarin Jahwe in die eerste persoon aan die woord is.

Hosea 11:1-11 bestaan op sy beurt weer uit drie onderafdelings, naamlik $1-4,5-7$ en $8-11$ :

- 1-4 is ' $n$ veroordelende terugblik op die geskiedenis van Israel. Dit is ' $n$ historiese aanklagrede. Hierdie terugblik laat twee dinge na vore tree: Enersyds Jahwe se liefde teenoor Israel. Andersyds Israel se ondankbare reaksie en ongehoorsaamheid. Om die noue liefdesband tussen Jahwe en Israel te illustreer, word die beeld van vader en seun aangewend. Dié metafoor wat origens baie selde in die $\mathrm{Ou}$ Testament voorkom, word heel dikwels by die godsdienste van die Nabye Ooste gebruik waar dit onlosmaaklik met die voorstelling van die veelgodedom verbind was. By Israel verkry die term ' $n$ ander funksie: Dit dui op Jahwe se liefde vir Israel. Deur adopsie, deur die sluiting van die verbond, deur Jahwe se konkrete liefdesdaad, naamlik die verlossing uit Egipte, word Israel Jahwe se seun. Om weer te herhaal: Hosea 11:1 wil deur terug te gryp na die uittog uit Egipte, beklemtoon dat Israel se enigste bestaansgrond geleë is in die liefde van en uitverkiesing deur Jahwe. 1-4 wil verder beklemtoon dat ten spyte van die hoogtepunt van die heilsgeskiedenis, naamlik die uittog uit Egipte, en ten spyte van Jahwe se liefdevolle versorging dwarsdeur die geskiedenis, Israel soos 'n rebelse kind is wat Jahwe se vaderlike liefde en sy roepstem herhaaldelik en op verskillende maniere versmaai het. Jahwe se liefdeshandeling lok 'n onverstaanbare en onverskoonbare reaksie van Israel uit: Hulle erken nie vir Jahwe as hulle Vader nie. Hosea 11:1-4 is eintlik dus ook die verhaal van die verlore seun wat die liefde van sy Vader in die grond vertrap het.

- 5-7 beweeg vanaf die verlede $(1-4)$ na die hede toe. Die aanklag (1-4) gaan oor in 'n strafaankondiging. Vanweë Israel se aanhoudende sonde is Jahwe se geduld op met hulle. Sy tugtiging kan nie meer uitbly nie. Omdat Israel hulle nie tot Jahwe wil bekeer nie $(s ̌ \bar{u} b$ ), sal Israel na Egipte toe moet terugkeer $(\tilde{s} \bar{u} b)$. Met die 'teruggaan na Egipte' toe word aangedui dat die heilsgeskiedenis opgehou het. Dit is die einde van Jahwe se pad met Israel. Die heilsgeskiedenis is ongedaan gemaak. Israel is weer waar hulle was voordat Jahwe hulle uit Egipte gered het. Assirië, in die agtste eeu v C is nou die 'nuwe 
Egipte' wat Israel verdruk. Assirië is instrument van Jahwe se tugtigende handeling. Israel staan op die punt om deur dié groot wêreldmag verwoes te word. Te midde van die strafaankondiging bly Jahwe egter nog praat van 'my volk' ('ammi - vs 7). Sowel uit dié term as uit die hele teksverband kan die afleiding gemaak word dat die strafaankondiging en oordeel nie Israel se vernietiging ten doel het nie, maar juis om hulle tot inkeer te bring.

- Met 8-11 bereik die boek Hosea sy teologiese hoogtepunt. Waar Jahwe in die voorafgaande verse oor Israel gepraat het, spreek Hy hulle nou direk in die tweede persoon aan. In plaas van die verwagte finale oordeelswoord tref ons hier 'n verrassende opheffing van skuld en 'n vryspraak aan. By wyse van retoriese vrae ('Maar hoe...? - vs 8) waarin Jahwe homself as 't ware ondervra, blyk enersyds die wroeging oor sy rebelse seun, maar ook Jahwe se liefde vir hom. Jahwe het alle reg om Israel te vernietig soos Adma en Sebojim (Adma en Sebojim is simbolies vir totale vernietiging en word saam met Sodom en Gomorra in een asem genoem, vgl Gen 10:19; 14:2, 8; Deut 29:23). In Jahwe se hart is daar as 't ware twee kragte aan die werk. Aan die een kant sy toorn as reaksie op die hardnekkige sonde van sy volk; aan die ander kant sy liefde en medelye met sy volk. Dan blyk dit dat sy liefde sterker is as sy toorn. Hy kan sy volk nie totaal vernietig en los nie. In plaas daarvan dat Hy Israel omkeer en verwoes, keer sy hart om. Die bekering, die omkering wat by Israel moes plaasgevind het, vind nou by Jahwe self plaas. Die moontlikheid tot redding lê nie by Israel nie, maar by Jahwe self. Sy liefde triomfeer oor sy toorn. Hy is bereid om 'n nuwe heilsgeskiedenis met sy volk te begin. Hy sal 'n nuwe uittog skep, 'n nuwe eksodus (vs 11), 'n nuwe bevrydingsdaad. Hy sal alles nuut maak. Weliswaar nie sonder gerig nie, maar deur die gerig heen.

Dit alles kan Jahwe doen juis omdat Hy God is (vs 9). Vir' $n$ mens is dit onmoontlik om troubrekers aan te hou liefhê. By Jahwe is dit wel moontlik. Terwyl die tōrā die doodstraf uitspreek oor 'n ongehoorsame kind (vgl Deut 21:18-21: 'Wanneer'n man 'n opstandige en ongehoorsame seun het wat nie na sy pa en ma wil luister nie,... Dan moet al die mans van die stad hom met klippe doodgooi'), is Jahwe bereid om sy ongehoorsame, rebelse seun te vergewe. Hosea laat ons byna aan die Pauliniese woord dink: 'Wat die wet nie by magte was om te doen nie, ... dit het God gedoen' (Rom 8:3). Hierdie woorde uit Hosea laat een van die kommentatore (Rudolph 1966: 218) sê: 'Hier ist Evangelium im 
Alten Testament.' Die heiligheid van Jahwe bestaan hier (vgl vs 9) juis daarin dat $\mathrm{Hy}$ by sy volk is; dat Hy Immanuel is; dat Hy aan 'n sondige volk wat die dood verdien weer eens 'n nuwe toekomsverwagting gee.

Dit is binne hierdie konteks dat Hosea 11:1 verstaan moet word.

\section{HOSEA 11:1 IN MATTEUS 2:15}

As ons getrou wil bly aan ons uitgangspunt dat die Ou Testament gesagvolle Woord is dan sal ons as Christene die boodskap van Hosea 11:1 vv steeds ernstig moet opneem. En as dit waar is dat Hosea 11:1-11 gesagvolle Woord is, dan kan die 'vervul' in Matteus 2:15 nie beteken dat die boodskap en betekenis van Hosea 11 verval of opgehef word nie. Dan beteken dit dat Hosea 11 èn Matteus 2 elkeen ' $n$ eie boodskap het.

Hosea 11:1-11 se boodskap kan soos volg gesistematiseer en saamgevat word:

- Ten spyte van Jahwe se liefdesdade aan Israel, tree Israel steeds soos 'n ongehoorsame, rebelse kind op.

- Alhoewel Jahwe volle reg het om vir Israel uit te wis, en te veroordeel,

- is Hy nogtans bereid om weer 'n nuwe begin met hulle te maak, om hulle sonde te vergewe, om onverdiende genade aan hulle te bewys en om die liefde oor die toorn te laat seëvier.

Dit hoef nie veel verbeelding te kos om aan te voel dat hierdie boodskap volkome in lyn is met die Blye Boodskap van die Nuwe Testament nie. Omdat die God van Hosea 11 dieselfde God is as die God van die Nuwe Testament is dit nie verbasend nie dat die boodskap van Hosea 11 korreleer met die basiese boodskap van die Nuwe Testament, naamlik dat God die wêreld ten spyte van hulle sonde só liefgehad het dat Hy sy Seun gestuur het om sy rebelse, sondige kinders weer ' $n$ keer 'n kans te gee om na Hom toe terug te keer. In Jesus Christus seëvier die liefde ook oor die toorn. In Hom leer ons ook die lydende God ken wat die straf nie op sondaars laat neerkom nie, maar op Homself.

\section{Literatuurverwysings}

ANDERSEN, FI \& FREEDMAN, DN 1981. Hosea. New York: Double Day \& Company. (Anchor Bible 24.) 
BAKER, DL 1976. Two Testaments one Bible. Leicester: Intervarsity Press.

BALENTINE, SE 1981. The interpretation of the Old Testament in the New Testamant. Southwestern Journal of Theology 23, 41-57.

DEN HEYER, CJ 1983. The Messiaanse weg I: Messiaanse verwachtingen in het OT en in de vroeg Joodse tradisie, Kampen: Kok.

GUNNEWEG, AHJ 1978. Understanding the Old Testament. London: SCM Press.

JEREMIAS, J 1983. Der Prophet Hosea. Göttingen: Vandenhoeck. (ATD 24/1.)

MAYS, JL 1978. Hosea. 3rd ed. London: SCM Press. (Old Testament Library.)

PREUSS, HD 1984. Das Alte Testament in christlicher Predigt. Stuttgart: Kohlhammer.

RUDOLPH, W 1966. Hosea. Gütersloh: Gerd Mohn. (KAT XIII/1.)

VAN LEEUWEN, C 1968. Hosea. Nijkerk: Callenbach. (POT.)

WOLFF, H-W 1965. Dodekapropheton 1: Hosea. Neukirchen-Vluyn: Neukirchener Verlag. (BKAT XIV/1.)

WOLFF, H-W 1982. Prophetische Alternativen: Entdeckungen des Neuen im Alten Testament. München: Kaiser. 